\title{
New Chinese Costume
}

\author{
Yuting $\mathrm{Xie}^{1^{*}}$ \\ ${ }^{1}$ Sino-French Institute of Fashion Designer, Shanghai University of Engineering Science, Shanghai, \\ China \\ *Yuting Xie, E-mail: 707516606@qq.com
}

Received: October 30, 2017 Accepted: November 28, 2017 Online Published: November 30, 2017 doi:10.22158/wjssr.v4n4p381 ～URL: http://dx.doi.org/10.22158/wjssr.v4n4p381

\begin{abstract}
At the 2014 APEC meeting, new Chinese costumes became a hot topic, and traditional Chinese elements were favored by insiders at home and abroad. Based on the development of new Chinese costume in recent years and the characteristics of the research, to grasp the contemporary people's demand for traditional clothing, combined with the fashion trend in inheriting traditional national culture, popular new innovation in new period of contracted type traditional clothing, meet the demand of different levels of people's wear, which not only promote the development of the apparel industry, have contributed to the prosperity of the cultural industry.
\end{abstract}

\section{Keywords}

traditional culture, Chinese costume, inherit, innovate

\section{Introduction}

15 In recent years, the Chinese style has been existed for a long time and has become more and more popular. Established on the basis of Chinese traditional culture, the Chinese style which contains a large number of Chinese elements and adapts to the global trend of popularity is affecting every aspect of people's life. In clothes, Chinese style clothing is quite popular, the emergence of new Chinese costume sets off a trend of China traditional costume. The so-called new Chinese costume, "Chinese" is the root, "Manner" is the soul, "New" is the form. Nowadays, research on new Chinese costume is extremely scarce. Styles of new Chinese costume are traditional and unified, of complicated workmanship. They look beautiful but are inconvenient to dress, and they brought problems to people's daily life, work. Now the new Chinese costume is mostly used for important occasions including interview and meeting of heads of state, it is difficult to integrate into the most basic "clothing", one of people's basic necessities of clothes, food, shelter and travel. Therefore, based on the traditional elements of new Chinese costume, it is the most important task of developing new Chinese costume to combine with the new design style, give it new life, extend to the daily life of the public. Combining Chinese elements with modern styles becomes the new dress which is more acceptable to the public, more modern and 
passed from mouth to mouth.

\section{Case}

16 years ago, beside Huangpu River, Shanghai, APEC economic leaders from all participating countries took a photo in "Tang suit" in front of Shanghai science and Technology Museum, which became a major highlight of the event. There is no doubt that "Tang suit" has become one of the key words of 2001 Shanghai APEC. Costumes with China traditional elements became popular. Until 2014, the 21 country leaders in elegant Chinese clothing completed the APEC meeting. The costume design at this conference starts from the basic concept, and integrates the all inclusive Chinese philosophy of harmony and diversity, which shows Chinese traditional culture to the guests and the world through the extraction of common design elements. Since then, new Chinese costume made its name.

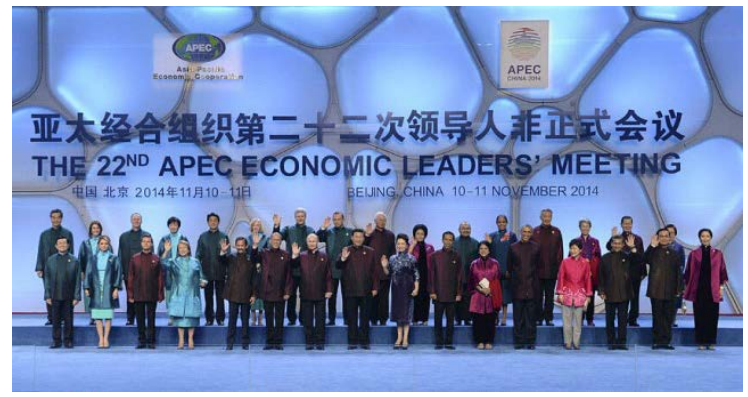

Figure 1. 2014 Shanghai APEC

Although the research and design of the new Chinese consume in domestic and foreign market is extremely deficient, in recent years, Chinese traditional design elements has not only attracted the attention of the industry insiders, but also gained preference of foreign designers.

In China, NE-TIGER (tiger) is currently the most influential luxury brand with carrying forward the traditional culture as the characteristics. NE•TIGRR picks the classic elements of national characteristics in each dynasty, leads Chinese costume culture with simple international fashion trend which emphasizes the three-dimensional profile.

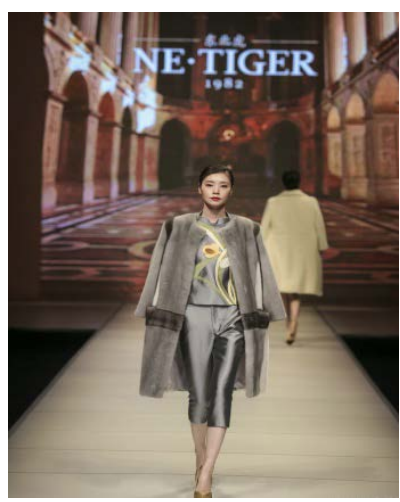




\section{Figure 2. NE•TIGRR}

“Tang•mirror" in 2012, "Hua•Song” in 2013, "Dig•Yuan" in 2014, haute couture Chinese costume shows, each show inherits and carries forward the traditional culture of the Chinese nation, develops the new Chinese costume to this day. Founder Zhang Zhifeng thinks that APEC is just a cohesive point, which enables more consumers to understand and focus on Chinese design and traditional crafts, and also satisfies consumers' pursuit of a better life and satisfaction with cultural confidence. The achievement of "Chinese dream" needs a carrier, the national culture heritage also needs such a carrier, but he feels that Chinese designer can accomplish such a task, so new Chinese consume is the best choice.

In the 2016 spring and summer men's clothing release of DOLCE \& GABBANA, the whole performance showed the audience an the world more than 100 sets of men's clothes with the theme of "Chinese elements". Tang suit and Chinese frog, emblazoned with the patterns of Chinese ancient palace, peacock, deep sense of Chinese style was amazing. The folk custom patterns of dragon and Phoenix, totem and swallow, which are the most characteristic of Chinese folk custom, have been added to the suit design with Italian style suit as prototype in the form of printing and dyeing and embroidery.

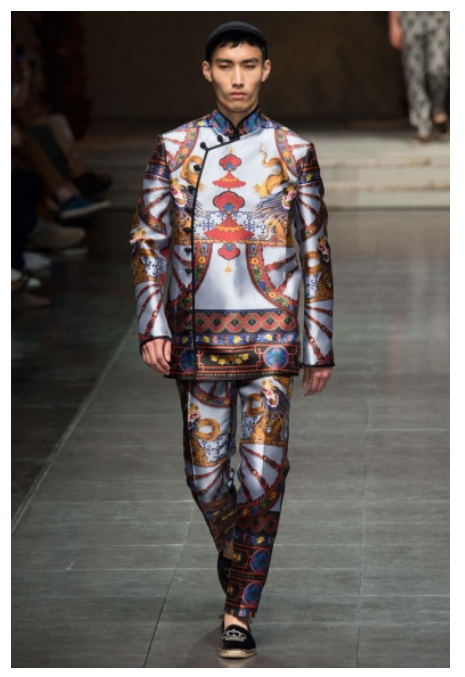

Figure 3. DOLCE \& GABBANA

\section{Conclusion}

Thus, China element has been popular overseas and widely used, but it is not difficult to find that most foreign designers only use some Chinese elements, apply it to their own clothing brand style, clothing products they made are complex and mixed, even the new Chinese costume made by the domestic designers has a complicated sense of design, orthodox design, which is not conducive to casual wear. Such clothes have excellent stage effect, and the prices are more expensive, more of them have been 
applied in a number of performances, parties, exhibitions and other big occasions. It is extremely difficult to really integrate into people's simple daily life, and the market demand of new Chinese consume which is simple and good to wear is greatly increased. How to design new Chinese consume which meets the public requirements and which is easy to wear, which integrates modern pop style with the traditional significance is the key.

Clothing is an important symbol of culture, and a channel to inherit and disseminate national culture. As the model of inheriting and innovating Chinese traditional costume culture, new Chinese consume carries the special expression significance. New Chinese consume has been gradually popularized in people's concept, accepted by the society. But the extent of its dissemination and promotion is far from enough. Its style is single, fabric is expensive, wearing occasions are limited, wearing process is complex, and comfort degree is low, and few people buy for casual wear. New Chinese consume belongs to the nation, it should break the existing pattern, integrate into the new life while retaining the original elements of traditional culture, infiltrate its new design style into the community, enable people to always have new Chinese consume to wear in daily life, and integrate into people's daily life, study and work. In the leisure time people may talk about dressing up of each other, spread people's love and respect for the traditional costumes, traditional culture through clothing, show the cultural creativity of our country at any time, show the soul charm of Chinese nation.

\section{References}

Li, J. W. (2015). The inheritance and exhibition of traditional elements of Chinese clothing from 2014 Beijing APEC. Art technology.

Liao, J., \& Xu, X. (2009). 100 years of Chinese clothing. Shanghai: Shanghai culture press.

Qian, X. P. (2005). The traditional Chinese process of silk weaving (pp. 338-339). Zhengzhou: elephant press.

Shen, C. W. (2005). Research on ancient Chinese clothing (p. 89). Shanghai: Shanghai bookstore press. Yang, Q. M. (2007). A study on the source of button clothing in China. Jiangsu: Suzhou University.

Zhang, L. H. (2007). Research on costume innovation design. In Application of fashion design.

Zhou, X. B. (1986). Ancient Chinese clothing history (p. 10). Beijing: China drama press.

Zhou, X., \& Gao, C. M. (1996). Great dictionary of Chinese clothing and clothing (pp. 245-246). Shanghai: Shanghai dictionary publishing house. 